\section{ADMINISTRASI TATA USAHA}

\section{BAB I PENDAHULUAN}

\section{BAB II METODE PENELITIAN}

Artikel ilmiah hendaknya disusun dengan metode dan langkah-langkah yang sistematis untuk memudahkan melakukan penelitian. Pada artikel ini, peneliti menggunakan metode studi literatur dengan cara mengumpulkan literature (bahan-bahan materi) yang bersumber dari buku, jurnal, dan sumber lainnya terkait ilmu tentang Administrasi Pendidikan. Berisi abstrak yang menerangkan ringkasan dan tujuan artikel, serta keyword untuk memudahkan pembaca dalam mencari kata kunci, beserta pendahuluan latar belakang artikel dan metode penelitian artikel serta inti dari isi artikel dan kesimpulan serta daftar pustaka.Disini penulis mengambil bahan berdasarkan sumber terpecaya artikel (Hadeafriansyah 2019).

\section{BAB III KAJIAN TEORI DAN \\ PEMBAHASAN}

\section{A. Prinsip-Prinsip Tata Ruang Kantor}

1. Pekerjaan harus mengalir terus menerus sedapat mungkin dalam garis lurus.

2. Bagian-bagian dan seksi-seksi yang berfungsi sama dan yang berhubungan harusditempatkan secara berdekatan untuk mengurangi waktu bepergian.

3. Aliran pekerjaan harus sederhana, sehingga dapat mengurangi hilir mudik pegawaidan penyampaian surat-surat dalam jarak yang pendek.

4. Meletakkan perlengkapan kantor harus dekat dengan pegawai yang menggunakannya.

5. Pergunakan meja dan kursi dengan ukuran yang sama dalam sebuah ruangan.

6. Menyusun meja harus sedemikian rupa sehingga tidak ada pegawai yang terpaksa menghadap pada sumber cahaya.

7. Kesatuan yang banyak berhubungan dengan masyarakat harus ditempatkan dibagian depan.

8. Satuan yang pekerjaan bersifat gaduh, sebaiknya ditempatkan dekat jendela dan hendaknya dijauhkan dari satuan lainnya.

9. Hendaknya tempat arsip-arsip 
kantor berada pada dinding atau susun tangga yang mudah terjangkau oleh petugas.

\section{B. Bentuk-Bentuk Tata Ruang Kantor}

\section{a. Tata Ruang Tertutup}

Suatu tata ruang dikatakan terpisah-pisah atau tertutup apabila susunan ruang untuk bekerja terbagi-bagi dalam beberapa bagian. Keuntungannya adalah moral pekerja atau staf tetap terjaga, pekerjaan yang sifatnya rahasia tetap terjaga, menghindari gangguan dari pekerja satu ke yang lainnya, pimpinan akan lebih tenang dalam mengerjakan tugasnya karena tidak terganggu oleh kegiatan para karyawan. Kelemahannya adalah pengawasan lebih sulit dilakukan karena terhalang oleh penyekat, cahaya sulit masuk dan udara sulit beredar sehingga suasana lebih pengap dan gerah, apabila diperlukan tukar tempat antara bagian yang satu dengan bagian yang lain sulit dilakukan dan sulit merubah ruangan, dan apabila terjadi penambahan pegawai atau alatalat kantor ataupun perubahan mengenai proses penyelesaian suatu pekerjaan agak sulit menampungnya.

\section{b. Tata Ruang Terbuka}

Dalam susunan ini ruang yang dipergunakan untuk ruang bekerja tidak dipisah pisahkan atau tidak menggunakan penyekat, tetapi semua aktivitasnya dilaksanakan pada satu ruang besar terbuka sehingga semua yang bekerja tampak mudah diamati dari satu sudut pandang.

1) Tata Ruang Kantor Semi Tertutup

Ruang kantor semi tertutup adalah ruang yang disekat hanya setinggi 1,5 meter. Keuntungan ruang kantor semi tertutup adalah untuk menjaga privasi kerja. Kerugian ruang kantor semi tertutup 
adalah perubahan tempat lebih sulit dilakukan.

2) Lingkungan Fisik Kantor

Salah satu yang harus
diperhatikan dalam
perencanaan gedung atau
fisik kantor adalah lokasi.
Disamping itu faktor
penting yang harus
mendapat perhatian adalah faktor lingkungan, apabila kehadiran suatu kantor tidak dikehendaki oleh lingkungan masyarakat maka kantor tersebut tidak dapat bertahan lama dan akhirnya akan mati. Karena itu pula faktor lain yang harus diperhatikan, diantaranya:
a) Pengembangan kantor dimasa yang akan datang.
b) Gambaran perkembangan wilayah dimasa datang.
c) Sumber tenaga

kerja dan kebutuhan kantor.

d) Udara yang bersih dan segar.

e) Ongkos pemeliharaan yang rendah.

f) Fasilitas-fasilitas angkutan yang lebih mudah.

\section{c. Faktor-Faktor}

yang

\section{Mempengaruhi Tata Ruang}

\section{Perencanaan Cahaya}

Penerangan cahaya yang baik akan diperoleh beberapa keuntungan, diantaranya:

a) Hasil pekerjaan atau produktivitas bertambah.

b) Kualitas pekerjaan lebih baik.

c) Kesalahan-kesalahan berkurang.

d) Semangat kerja pegawai lebih baik.

e) Mengurangi ketegangan dan kelelahan.

f) Prestise lebih baik untuk perusahaan. 


\section{Perencanaan Warna}

Dengan menggunakan warna yang tepat dan baik akan diperoleh keuntungan diantaranya:

a) Kantor menjadi tampak menyenangkan dan menarik pandangan

b) Mempunyai akibat yang tidak langsung terhadap efisiensi dan produktivitas pegawai.

c) Mencegah kesilauan akibat cahaya yang berlebihan.

d) Memelihara kegembiraan, ketenangan dan semangat bekerja pegawai.

e) Mengurangi rasa tertekan sehingga pegawai merasa lega dan bebas.

\section{Peranan Guru dalam Tata Usaha}

Telah dikatakan di depan bahwa administrasi tata usaha adalah kegiatan melakukan pencatatan untuk segala sesuatu yang terjadi dalam sekolah untuk digunakan sebagai bahan keterangan bagi pimpinan.

Telah disebutkan pula bahwa tugas utama guru yaitu mengelola proses belajar mengajar di sekolah. Sekolah merupakan sub sistem pendidikan nasional dan di samping sekolah, system pendidikan nasional itu juga mempunyai komponen, komponen lainya. Guru harus juga memahami apa yang terjadi di lingkungan kerjanya.

Di sekolah guru berada dalam kegiatan administrasi sekolah, terutama ketata usahaan sekolah.Sekolah melaksanakan kegiatanya untuk menghasilkan lulusan yang jumlah serta mutunya telah ditetapkan. Dalam lingkup administrai atau ketata usahaan sekolah itu peranan guru amat penting, seperti penetapkan kebijaksanaan dan melaksanakan proses perencanaan, pengorganisasiaan, pengarahan, pengkoordinasiaan, pembiayaan, dan penilaian kegiatan kurikulum, kesiswaan, sarana prasarana sekolah, personalia sekolah, keuangan dan hubungan sekolah-masyarakat guru harus memberikan sumbangan baik tenaga maupun pikiran.

Administrasi sekolah terutama yang berkaitan dengan ketata usahaan adalah pekerjaan yang bersifat kolaboratif, artinya pekerjaan yang didasarkan atas kerja sama, dan bukan bersifat individual. Oleh karena itu semua 
personel sekolah terutama guru harus ikut terlibat.

Ada beberapa hal yang bisa dilakukan oleh seorang guru dalam hal ke-tata usaha-an di sekolahnya. Di antaranya ;

\section{Pencatatan Murid}

Pencatatan terhadap siswa ini terutama adalah siswa baru-siswa perkelaspersemester-dan yang mengulang kelasnya, pindahan, serta jumlah siswa yang keluar karena lulus atau bahkan karena drop out. Dengan pencatatan inilah maka dengan mudah diketahui jumlah siswa dan perkembangannya pada setiap tahun ajaran.

Di samping itu tugas lainnya adalah pencatatan daftar hadir siswa, dalam rangka untuk menghitung keaktifan siswa dan partisipasinya dalam kerjasama dan sebagai alat kontrol dalam menegakkan tata tertib sekolah.Dan yang terpenting adalah data tentang prestasi muridnya.Untuk dapat melihat kemajuan atau kemunduran dengan segera dapat dilihat dari dokumentasi siswa tersebut.Semua hasil pencatatan ini diperlukan sekali sebagai bahan laporan yang nyata kepada atasannya.Oleh karena itu tidak boleh hilang atau rusak.Dokumentasi ini bisa juga sebagai bahan laporan untuk orang tua siswa.

\section{Pencatatan tentang Guru}

Data tentang keadaan guru harus dicatat dengan baik, terutama tentang jumlah, data pribadi, masa kerja, dan bahan untuk usulan kenaikan pangkatnya dan gaji berkala.Demikian pula kehadiran guru melaksanakan tugas sebagai pegawai, terutama PNS, yang sangat berguna untuk pembinaan guru itu selanjutnya. Pada gilirannya nanti semua data itu akan berguna sebagai bahan bimbingan, perencanaan, pengawasan, koordinasi dan pendidikannya. Data yang dicatat dengan rapi dan lengkap akan sangat menunjang untuk mengatasi masalah yang dialami sekolah maupun pribadi guru itu sendiri. Data yang lengkap akan memberikan petunjuk untuk mengambil keputusan bagi kepala sekolah.

\section{Pencatatan Proses Belajar Mengajar (PBM)}

Hal ini akan mempengaruhi bagi kelancaran proses pendidikan di 
sekolahnya.

\section{Penertiban Buku-buku Tata Usaha}

Mengingat kegiatan komunikasi lembaga pendidikan baik secara lisan maupun tertulis dengan pihak luar dan dalam lembaga pendidikannya. Komunikasi dalam bentuk tertulis dilaksanakan melalui surat, telegram, nota, dan lain-lain. Sehingga perlu penertiban surat-menyurat ini, baik surat masuk maupun surat keluar. Buku-buku tata usaha di antaranya;

a. Buku agenda

b. Buku arsip

c. Buku ekspedisi

Masih banyak kesempatan lain yang mengharuskan guru ikut berperan atau terlibat dalan administrasi sekolah, terutama berkaitan dengan tata usaha sekolah, Beberapa di antaranya ialah:

1. Merencanakan penggunaan ruang-ruang di sekolah

2. Merumuskan kebijakan tentang pembagian tugas mengajar gurugurua.

3. Menyelidiki buku-buku sumber bagi guru dan buku-buku pelajaran bagi murid-murid

4. Berperan dalam hal suratmenyurat di lingkungan sekolah

5. Berperan sebagai penerima, penyortir, pencatat, pengarah, pengolah, peñata arsip pada proses surat menyurat.

a. Menyelidiki buku-buku sumber bagi guru dan buku-buku pelajaran bagi murid-murid

b. Berperan dalam hal suratmenyurat di lingkungan sekolah

c. Berperan sebagai penerima, penyortir, pencatat, pengarah, pengolah, peñata arsip pada proses surat menyurat.

\section{BAB IV KESIMPULAN}

Telah dikatakan di depan bahwa administrasi tata usaha adalah kegiatan melakukan pencatatan untuk segala sesuatu yang terjadi dalam sekolah untuk digunakan sebagai bahan keterangan bagi pimpinan.

\section{DAFTAR PUSTAKA}

Afriansyah. H. (2019). Administrasi Tata Usaha. Padang. 
